\title{
ANALISIS KOMPONEN KIMIA AKTIF ISOLAT DAUN Colocasia esculenta L. IDTK01 SECARA SPEKTROFOTOMETER INFRA MERAH
}

\author{
Herwin ${ }^{\star}$, Muzakkir Baits, Ririn, Ayyub Harly Nurung \\ Fakultas Farmasi, Universitas Muslim Indonesia Makassar \\ *Email: herwin.herwin@umi.ac.id
}

\begin{abstract}
The objective of this research is to analysis chemical coumpounds active isolate of Colocasia esculenta L.'s leaves IDTK01 using infra red spectrophotometer. The fractionation of the ethanolic extract of Colocasia esculenta L's leaves using liquid vacuum chromatography obtained 7 fractions. Active fraction was $B$ fraction isolated from the active coumpound by TLC-preparative from 3 different isolate, IDTK01, IDTK02 dan IDTK03. IDTK01 isolate was tested its antibacterial activity using TLCbioautography with eluen $n$-hexane:ethyl acetate (10:1) and its active against Salmonella thypi with $R f$ value 0.98. Active isolate IDTK01 was analyze its active bacterial coumpound using infrared spectrophotometer and the results is hydrogen bond, hydroxyl functional group (OH), aryl/ aromatic $(\mathrm{C}=\mathrm{C})$, aliphatic $\left(\mathrm{CH}_{2}\right)$, Ether aldehyde $(\mathrm{C}-\mathrm{O})$, and pyridine.
\end{abstract}

Key Words: Colocasia esculenta L., isolate IDTK01, chemical coumpound, infrared spectroscopy, antibacterial.

\section{PENDAHULUAN}

Penelusuran suatu seyawa dalam bahan alam pada tumbuhan atau tanaman sebagai senyawa obat baru semakin berkembang. Pemanfaatan bahan alam tersebut memperjelas adanya pemanfaatan senyawa sebagai metabolit sekunder dalam tumbuhan sebagai sumber bahan baku obat. Adanya metabolit sekunder tersebut desebakan karena adanya metaboit sekunder tersebut terbukti memiliki mekanisme kerja sebagai antikanker, antibakteri dan antioksidan alami diantaranya adalah golongan senyawa alkaloid, tanin, polifenol dan turunannya sebagai obat alami dengan efek samping yang sangat rendah. Dengan adanya metabolit sekunder tersebut, penelusuran dan pemanfaatan bahan alam sangat perlu adanya berbagau pegujian baik secara in-vitro maupun in-vivo.

Tumbuhan atau tanaman yang secara alami memiliki metabolit sekunder adalah tumbuhan dengan genus Colocasia. Genus pada tumbuhan ini memiliki species Colocasia esculenta L. yang mana daunnya dapat dimanafaatkan sebagai obat infeksi pada kulit bernanah, berak darah, bisul, dengan kandungan kimia aktif yaitu saponin, terpen, tanin, flavonoid, flobatanin, antraquinon, glikosida jantung, dan alkaloid. ${ }^{1}$ Tanaman talas merupakan herba yang termasuk suku talastalasan (Araceae). Tanaman talas diduga memiliki golongan senyawa kimia flavonoid dan saponin $^{2}$ dan karakterisasi bercak daun talas menggunakan pereaksi $\mathrm{AlCl} 3$ positif mendandung flavonoi. ${ }^{3}$ Berdasarkan hasil indentifikasi golongan komponen kimia dari fraksi daun Colocasia esculenta L. Memiliki senyawa flavonoid ${ }^{4}$ dimana senyawa golongan flavonoid tersebut salah satunya adalah senyawa Bis(2-Ethylhexyl) Phtalate. ${ }^{5}$ Selain dari daun dari yang bermanfaat sebagai antibakteri, bagian lain yang dapat bersifat sebagai anti 
bakteri adalah umbinya, yang secara KLTBioautografi bahwa ekstrak etanol umbi Colocasia esculenta L. dapat memberikan aktivitas terhadap bakteri patogen pada nilai Rf 0.38 pada golongan komponen kimia alkaloid. ${ }^{6}$ Maka dari latarbelakang tersebut, maka dilakukan analisis komponen kimia pada golongan senyawa kimia lainnya yang berpotensi sebagai antibakteri pada daun Colocasia esculenta L. secara spektrofotometri inframerah.

\section{METODE PENELITIAN}

\section{Alat Dan Penelitian}

Alat yang digunakan adalah timbangan analitik, autoklaf, oven, laminar air flow (LAF), inkubator, KLT-Preparatif, spektofotometri UV-visible, Spektrofotometri infra merah (Merek Shimadzu). Bahan yang digunakan adalah fraksi B daun Colocasia esculenta L., aquadest, bakteri Salmonella thypi, ATTC 2019), kloroform p.a (E.Merck), n-heksan p.a (E.Merk), etil asetat p.a (E.Merk), larutan $\mathrm{NaCl}$ fisiologis 0,9\%, medium NA (Nutrien Agar), metanol p.a (E.Merk).

\section{Presedur Penelitian}

Isolasi Senyawa Aktif Fraksi B Daun Colocasia esculenta L. Secara KLTPreparatif

Fraksi B yang diperoleh dilakukan isolasi senyawa aktif dengan menggunakan metode KLT-Preparatif dengan fase dian Silika Gel P254 dan fase gerak n-heksan : etil asetat (10:1) kemudian dikerok dan senyawa yang diperoleh dilarutkan dengan menggunakan pelarut klorofom p.a. ${ }^{7}$

\section{Uji Kemurnian}

Uji kemurnian dilakukan dengan menggunakan KLT Dua dimensi. Isolat IDTK01 dilarutkan dengan menggunakan kloroform : methanol p.a (1:1) kemudian ditotolkan pada lempeng KLT berukuran 10xq10 $\mathrm{cm}$ kemudian dielusi menggunakan eluen $\mathrm{n}$-heksan : etil asetat (10:1) dan (1:1). Bercak pada lempeng kromatogram dilihat pada UV $254 \mathrm{~nm}$ dan 366nm. ${ }^{7}$

\section{Pengujian Aktivitas Isolat Daun Colocasia} esculenta L. IDTK01 Terhadap Bakteri Salmonella thypi Secara KLT-Bioautografi

Isolat murni daun Colocasia esculenta L. IDTK01 hasil isolasi yang telah diketahui golongan komponen kimianya ditotolkan pada lempeng kromatografi lapis tipis (KLT) dengan ukuran $7 \times 1 \mathrm{~cm}$, lalu dielusi dalam chamber yang berisi eluen (fase gerak) n-heksan : etil asetat (10:1). Setelah terelusi pada lempeng dibiarkan kering, lalu dimasukkan ke dalam cawan petri, dengan cara penempelan antara permukaan medium Nutrien Agar (NA) yang telah diinokulasi bakteri patogen Salmonella typhi dengan permukaan isolat yang telah ditotol, kemudian dibiarkan berdifusi selama 60 menit lalu diangkat. Diinkubasi pada suhu $37^{\circ} \mathrm{C}$ selama $1 \times 24$ jam. Diamati zona hambat terhadap bakteri patogen pada medium dan diukur nilai $\mathrm{Rf}$ isolat aktif pada lempeng $\mathrm{KLT}{ }^{6}{ }^{6}$

Analisis Komponen Kimia Aktif Isolat Daun Colocasia esculenta L. IDTK01 Secara Spektrofotometri Infra Merah

Isolat fraksi daun Colocasia esculenta L. yaitu isolate IDTK01 dianalisis secara sspektrofotometri infra merah (menentukan gugus fungsi) (Merek Shimadzu) dengan menggunakan pelet $\mathrm{KBr}$. Campuran pelet $\mathrm{KBr}$ di ukur puncak serapannya. ${ }^{8}$

\section{HASIL DAN PEMBAHASAN}

Isolasi Senyawa Aktif Daun Colocasia esculenta L. Fraksi B Secara Secara KLTPreparatif

Fraksi B sebagai fraksi aktif dari ekstrak etanol daun Colocasia esculenta L. diisolasi 
Analisis Komponen Kimia Aktif Isolat Daun Colocasia esculenta L. IDTK01 Secara Spektrofotometer Infra Merah

senyawa aktif secara KLT-Preparatif dengan ukuran lempeng 20x20 cm menggunakan eluen n-heksan : etil asetat (10:1) diperoleh 3 isolat yaitu dengan kode isolate IDTK01, IDTK02 dan

IDTK03. Hasil isolasi terlihat pada tabel 1, Gambar 1.

Tabel 1. Hasil KLT-Preparatif Fraksi B Ekstrak etanol daun Colocasia esculenta L. Secara KLTPreparatif.

\begin{tabular}{cccc}
\hline \multirow{2}{*}{ Fraksi } & \multirow{2}{*}{ Bercak } & \multicolumn{2}{c}{ Warna Bercak } \\
\cline { 3 - 4 } & 1 & UV 254 nm & UV 366 nm \\
\hline \multirow{2}{*}{ B } & 2 & Kuning & Coklat \\
& 3 & - & Berpendar \\
& & Coklat & Orange \\
\hline
\end{tabular}

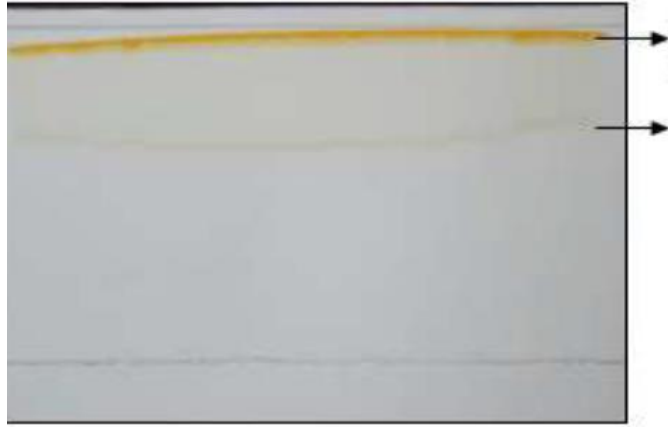

Gambar 1. Isolasi Senyawa Fraksi Daun Colocasia esculenta L. Secara KLT-Preparatif dengan eluen n-Heksan : Etil Asetat (10:1)

Pengujian Aktivitas Isolat Daun Colocasia

esculenta L. IDTK01 Terhadap Salmonella

thypi Secara KLT-Bioautografi

Isolat Daun Colocasia esculenta L.

IDTK01 hasil KLT-Preparatif, dilakukan uji

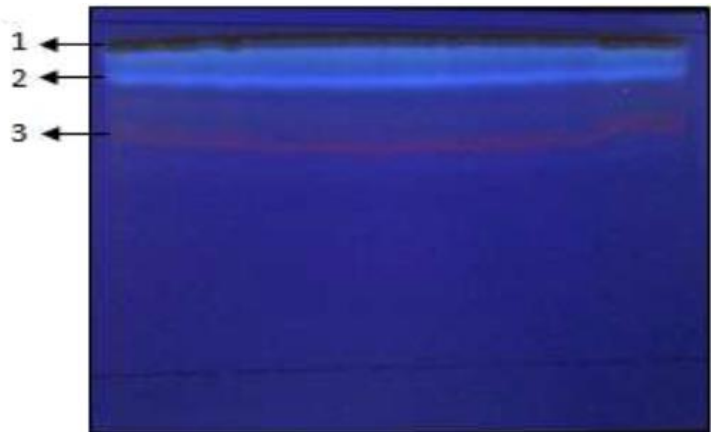

aktivitas secara KLT-Bioautografi dengan eluen n-heksan : etil asetat (10:1) diperoleh nilai Rf 0.98 aktif pada bakteri Salmonella thypi, sebagaimana pada tabel 2 .

Tabel 2. Hasil pengujian aktivitas antibakteri isolat daun Colocasia esculenta L. IDTK01 secara KLTBioautografi

\begin{tabular}{ccccc}
\hline \multirow{2}{*}{ Nama Isolat } & \multirow{2}{*}{ Nilai Rf } & \multicolumn{2}{c}{ Warna Bercak } & \multirow{2}{*}{ Bakteri Uji } \\
\cline { 3 - 4 } IDTK01 & 0.98 & UV 254 nm & UV 366 nm & \\
\hline
\end{tabular}

Analisis Komponen Kimia Aktif Isolat Daun Colocasia esculenta L. IDTK01 Secara Spektrofotometri Infra Merah

Isolat aktif daun Colocasia esculenta L. yaitu isolate IDTK01 dianalisis secara spektrofotometer infra merah (merek shimadzu) untuk menentukan gugus fungsi isolat diperoleh 18 peak dan hasil analisis diperoleh 13 peak, sebagaimana terlihat pada tabel 3, gambar 2 .

Kromatografi lapis tipis preparatif dilakukan untuk mengisolasi senyawasenyawa tunggal yang ada pada fraksi aktif. Pemisahan senyawa hasil KLT-preparatif dengan cara dikerok dan dipisahkan antara bagian atas bagian tengah dan bagian bawah. KLTpreparatif berguna untuk memisahkan campuran reaksi sehingga diperoleh senyawa murni berdasarkan hasil pengerokan dari berbagai pemisahan senyawa pada pita-pita yang terbentuk pada preparatif. Hasil pemisahan secara KLT-preparatif dari fraksi B daun Colocasia esculenta L. diperoleh 3 pita 
Analisis Komponen Kimia Aktif Isolat Daun Colocasia esculenta L. IDTK01 Secara Spektrofotometer Infra Merah

yaitu pita 1, pita 2 dan pita 3. Pita yang telah dikerok dilarutkan dengan menggunakan kloroform : metanol (1:1) untuk memisahkan antara silica (fase diam) dengan senyawa aktif.

Senyawa yang diperoleh yaitu senyawa Colocasia esculenta L. yaitu kode IDTK01 dilakukan pengujian aktivitas antibakteri. Hasil penelitian sebelumnya bahwa fraksi daun Colocasia esculenta $L$. secara difusi agar memiliki potensi sebagai antibakteri dan bersifat sebagai antioksidan berdasarkan pada penyemprotan menggunakan diphenilphikril hidrazil yang menunjukkan bahwa fraksi tersebut adalah golongan senyawa flavonoid (Herwin, 2015). Hasil pengujian aktivitas antibakteri secara KLTBioautografi senyawa IDTK01 menggunakan fase gerak n-heksan : etil asetat (10:1) aktif terhadap balteri Salmonella thypi dengan nilai Rf 0.98 .

Tabel 3. Analisis komponen senyawa Colocasia esculenta L.

\begin{tabular}{|c|c|c|c|c|}
\hline Fraksi & $\begin{array}{c}\text { Kode } \\
\text { Senyawa }\end{array}$ & Bilangan Gelombang $\left(\mathrm{cm}^{-1}\right)$ & Gugus Fungsi & Intensitas Peak \\
\hline \multirow{13}{*}{ B } & \multirow{13}{*}{ IDTK01 } & 3702.49 & Ikatan Hidrogen & Lemah \\
\hline & & 3619.54 & $\mathrm{OH}$ & Sedang \\
\hline & & 3019.65 & $\mathrm{OH}$ & Kuat \\
\hline & & 2929 & $\mathrm{C}-\mathrm{H}$ (aldehid) & Lemah \\
\hline & & 2400.49 & C-C & Sedang \\
\hline & & 1522.85 & $\mathrm{C}=\mathrm{C}$ (aril), $\mathrm{C}=\mathrm{C}$ aromatik & Lemah \\
\hline & & 1425.44 & $\mathrm{CH}_{2}$ alifatik & Lemah \\
\hline & & 1216.16 & $\mathrm{C}-\mathrm{O}$, (eter) & Kuat \\
\hline & & 1046.42 & C-O & Sedang \\
\hline & & 928.76 & $\mathrm{C}-\mathrm{H}$ & Sedang \\
\hline & & 769.62 & $\mathrm{C}-\mathrm{H}$ (alken) & Kuat \\
\hline & & 669.32 & $\mathrm{C}-\mathrm{C}-\mathrm{CHO}$ (aldehida) & Sedang \\
\hline & & 625.92 & piridin & Lemah \\
\hline
\end{tabular}

(థIIMADZU

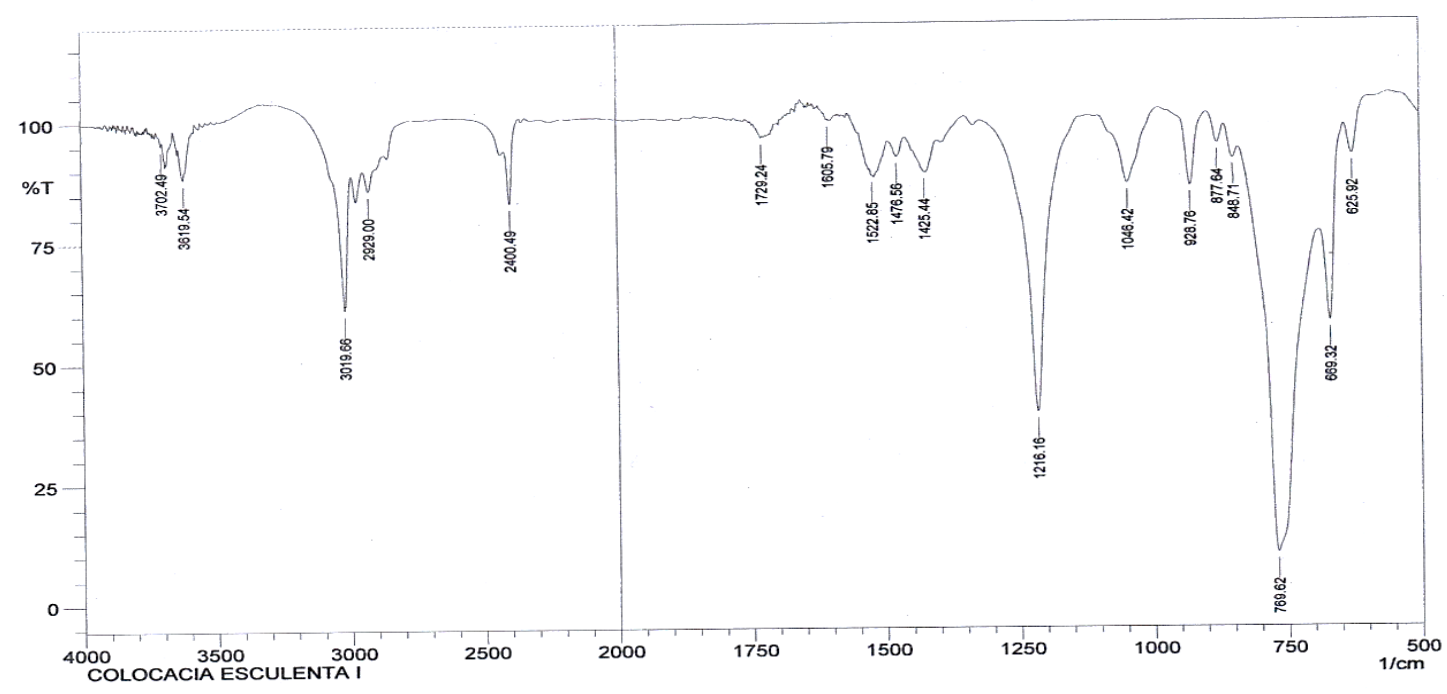

Gambar 2. Hasil Analisis Isolasi Daun Colocasia esculenta L. IDTK01 Secara Spektrofotometer Infra Merah 

Infra Merah

Hasil interprestasi data spektrum infra merah isolat IDTK01 diperoleh 13 peak dengan interpretasi hasil pada bilangan gelombang $3702,49 \mathrm{~cm}^{-1}$ menunjukkan adanya ikatan hidrogen dengan intensitas lemah, bilangan gelombang $3619.54 \mathrm{~cm}^{-1}$ (sedang) dan 3019.65 $\mathrm{cm}^{-1}$ (kuat) merupakan gugus $\mathrm{OH}$ (hidroksil), bilangan gelombang $2929 \mathrm{~cm}^{-1}$ (lemah) adalah gugus $\mathrm{C}-\mathrm{H}$ (aldehid), bilangan gelombang $2400,49 \mathrm{~cm}^{-1}$ (sedang) adalah gugus C-C, bilangan gelombang $1522,85 \mathrm{~cm}^{-1}$ (lemah) adalah gugus $\mathrm{C}=\mathrm{C}$ (aril), $\mathrm{C}=\mathrm{C}$ aromatic, bilangan gelombang $1425.44 \mathrm{~cm}^{-1}$ (lemah) adalah gugus $\mathrm{CH}_{2}$ alifatik, bilangan gelombang $1216.16 \mathrm{~cm}^{-1}$ (kuat) dan $1046.42 \mathrm{~cm}^{-1}$ (sedang) adalah gugus $\mathrm{C}-\mathrm{O}$ (eter), bilangan gelombang $928.76 \mathrm{~cm}^{-1}$ (sedang) adalah gugus $\mathrm{C}-\mathrm{H}$ (aldehid), bilangan gelombang $928.76 \mathrm{~cm}^{-1}$ (sedang) dan $769.62 \mathrm{~cm}^{-1}$ (kuat) adalah gugus $\mathrm{C}-\mathrm{H}$ (aldehid), bilangan gelombang $669.3 \mathrm{~cm}^{-1}$ (sedang) adalah gugus $\mathrm{C}-\mathrm{C}-\mathrm{CHO}$ (aldehida) dan bilangan gelombang $625.92 \mathrm{~cm}^{-1}$ (lemah) adalah gugus piridin. ${ }^{9,10}$

\section{KESIMPULAN}

Berdasarkan hasil penelitan disimpulkan bahwa hasil analisis isolat daun Colocasia esculenta L. dengan kode IDTK01 secara KLT-Bioautografi aktif terhadap bakteri Salmonella thypi dengan nilai $\mathrm{Rf} 0.98$ dan secara spektrofotometri infra merah diperoleh gugus fungsi $\mathrm{OH}$ (hidroksil), $\mathrm{C}=\mathrm{C}$ (aril/aromatik), $\mathrm{CH} 2$ alifatik, C-O (eter) aldehid dan piridin.

\section{DAFTAR PUSTAKA}

1. Bhagyashree R. Antihepatotoxic Activity Of Colocasia esculenta Leaf Juice. Int J Adv Biotechnol Res 2011; 2: 296-304.

2. Wijaya B, Citraningtiyas G, Wehantouw F. Potensi Ekstrak Etanol Tangkai Daun Talas
(Colocasia esculenta L.) Sebagai Alternatif Obat Pada Luka Kelinci (Oryctolagus cuniculus). Pharmacon J IIm Farm 2014; 3: 211-219.

3. Fadlila NW, Yuliawati MK, Syafnir L. Identifikasi Senyawa Aktif Antibakteri Dengan Metode Bioautografi KLT Terhadap Ekstrak Etanol Tangkai Daun Talas (Colocasia esculenta L.) Schott. In: Prosiding Penelitian SpeSIA, ISSN 24606472, Unisba. 2015, pp. 583-590.

4. Baits M, Herwin, Ririn. Aktivitas Antibakteri Fraksi-Fraksi Daun Colocasia esculenta L. Terhadap Salmonella thypi, dan Staphylococcus aureus Secara Bioautography-TLC. J As-Syifaa 2016; 8: 92-97.

5. Herwin, Nuryanti S, Sjafaraenan, et al. Antibacterial Activity of Bis (2-Ethylhexyl) Phtalate Leaves Fraktion Colocasia esculenta L. Againts Enteric Gram Negative Bacteria. J Glob Pharma Technol 2020; 12 : 130-139.

6. Hibai YRA, Herwin, Kosman R. Antibacterial Activity Assay of Ethanolic Extract of Bulbs sticky Taro (Colocasia esculenta) Use TLCBioautografi. J As-Syifaa 2015; 07: 76-84.

7. Fransiska K, Taebe B, Yulianty R, et al. Separation And Caracterisation of Chemical Compounds from Ethanol Extract of Taro Tuber (Colocasia esculenta Scott var. antiquorum). J Pharm Med Sciecens 2019; 4: $20-25$.

8. Sulastri L, Simanjuntak P. Senyawa Kimia Sterol Dari Kultur Jaringan Keladi Tikus (Typhonium divaricatum Decne). J IIm Manuntung 2019; 5: 153-160.

9. Linington RG, Williams PG, MacMillan John B. Problems in Organic Structure Determination A Practical Approach to NMR Spectroscopy. CRC Press., 2016

10. Silverstein RM, Webster FX, Kiemle D, and Bryce DL. Spectrometric Identification of Organic Compounds,7th ed. New York: Wiley, 2007. 